\title{
Maternal Infanticide and Filicide in a Psychiatric Custodial Institution in Hong Kong
}

\author{
D Tang, B Siu
}

\begin{abstract}
Objective: The aim of this study was to review the history, legislation, and psychiatric perspective of filicide, to compare the characteristics of mothers who committed neonaticide versus infanticide, and to discuss the infanticide law in Hong Kong.

Methods: Data of mothers remanded to the Siu Lam Psychiatric Centre from 2008 to 2016 for filicide were reviewed, as were data of filicide from the Child Fatality Review Reports published by the Social Welfare Department.

Results: From 2008 to 2016, eight mothers were remanded to Siu Lam Psychiatric Centre for filicide. Four were convicted of infanticide; the other four were convicted of manslaughter. Those convicted of infanticide were single and aged $<18$ years. They had concealed their pregnancies and received no antenatal care. They delivered at home and then either smothered or abandoned the newborn. They reported no suicidal attempts after the index offence and had no record of mental illness. They were given supervision orders instead of prison sentences. In contrast, those convicted of manslaughter were in their 30 s and married. They were documented to have killed the victims by charcoal burning, strangulation, mutilation, or defenestration. They all attempted suicide immediately after the killing and had histories of mental illness: paranoid schizophrenia $(\mathrm{n}=2)$, severe depressive disorder with psychotic symptoms $(\mathrm{n}$ $=1)$, and recurrent depressive disorder $(n=1)$. They were sentenced to Hospital Orders for unspecified periods.

Conclusions: In Hong Kong, the incidence of maternal filicide is low. However, the infanticide provision grants leniency to mothers, including those who show no evidence of mental illness.
\end{abstract}

Key words: Hong Kong; Infanticide

Dr Dorothy Tang, MBBS (HK), MRC Psych (UK), FHKC Psych, FHKAM (Psychiatry), Department of Forensic Psychiatry, Castle Peak Hospital, Hong Kong.

Dr Bonnie Siu, MBChB (HK), MRC Psych (UK), FHKC Psych, FHKAM (Psychiatry), FRC Psych (UK), Department of Forensic Psychiatry, Castle Peak Hospital, Hong Kong.

Address for correspondence: Dr Dorothy Tang, Department of Forensic Psychiatry, Castle Peak Hospital, 15 Tsing Chung Koon Road, Tuen Mun, New Territories, Hong Kong.

Tel: (852)2456 7111; Fax: (852) 2463 1644; Email: tyy551@ha.org.hk

Submitted: 3 April 2018; Accepted: 25 June 2018

\section{Introduction}

Filicide is murder of a child by a parent; infanticide is murder of a child within the first year of life; neonaticide is murder of a child within the first 24 hours after birth. ${ }^{1,2}$ Parents are the main suspect in two thirds of cases in which a child is killed. ${ }^{3}$ The rate of filicide is higher in mothers than fathers, ${ }^{4}$ although fathers are equally likely to murder their adult offspring. ${ }^{5}$ More boys than girls are murdered by their parents in Western countries, but more girls than boys are murdered by their parents in India and China. ${ }^{6,7}$ The present study aims to review the history, legislation, and psychiatric perspective of filicide, to compare the characteristics of Hong Kong mothers who committed neonaticide versus infanticide, and to discuss the infanticide law in Hong Kong.

\section{History}

In ancient times, infants were sacrificed to pagan gods. Ancient Greeks exposed unwanted newborns to the elements as a method of population control. ${ }^{8}$ In Egypt, children were entombed with their dead parents to provide companionship. In ancient Jericho and Germany, children were immured in the foundations of new buildings to assure stability. In ancient Asian countries, female infants were drowned or smothered owing to low socioeconomic status. In the Middle Ages, killing of children was finally described as a wrongdoing. In medieval Europe, 'overlaying' (mother lies on the infant to smother it to death) was a common method of infanticide and was described as a venial sin in priests' prayer book of penance. ${ }^{9}$ By the 17th century, in North America and England, concealment of a murdered newborn became a capital offence..$^{10}$ By 1888 , most European states except England established a legal distinction between infanticide and murder, with more lenient penalty for mothers with mental illness who committed infanticide. ${ }^{9}$ In 1922, England passed the Infanticide Act (amended 
in 1938) in recognition that women were biologically vulnerable to psychiatric illness at the time of child rearing, and mandated probation and psychiatric treatment. By the late 20th century, 29 countries had adjusted the penalty for infanticide in recognition of the biological changes that occur at childbirth. ${ }^{9}$ However, in the United States, there is still no infanticide legislation. Attempts have been made to introduce infanticide laws (eg, an act in 2009 in Texas) to replace the insanity defence in cases of infanticide and to classify infanticide as a crime distinct from murder. The proposed legislation was voted out of the committee and never introduced to the full legislative body. ${ }^{11}$ The perpetrator may face a long prison sentence or even the death penalty. ${ }^{12}$ Nonetheless, the prevalence of infanticide is comparable in countries that mandate treatment or punishment. ${ }^{13}$

\section{Epidemiology}

Approximately 95,000 children are murdered each year globally. ${ }^{14}$ The incidence of infanticide in industrialised countries (England, Scotland, Wales, US, Canada, New Zealand) ranges from 2.4 to 8.0 per 100,000 births, whereas the incidence of neonaticide ranges from 0.07 to 8.5 per 100,000 births..$^{4,15-18}$ However, the incidence of child homicide is likely to be underestimated, especially infanticide and neonaticide, as the victims' bodies are easily concealed, the police may not file a report, and the local courts may not prosecute despite evidence of homicide in medical reports. ${ }^{19}$ Furthermore, the cause of death may be falsely attributed to sudden infant death syndrome; up to $10 \%$ of such cases were estimated to be undetected homicides..$^{20}$ The addition of an 'undetermined' category to International Classification of Diseases may also render underreporting of infant homicides. ${ }^{21}$

\section{Motives}

Multiple methods of killing a child have been reported, with women more likely to use their hands as a weapon and less likely to use firearms, compared with men. ${ }^{22}$ Several different motives for infanticide have been identified. ${ }^{23,24}$

\section{Altruistic \\ The mother kills the child because the mother perceives this to be in the child's best interest, based on psychotic or non- psychotic reasoning. Mothers with postpartum depression may have acute feelings of failure to measure up to society's standards of 'good mothers/wives', fears about the infant's health and well-being, or anxiety or doubts about their ability to care for the infant. Postpartum depression is associated with a history of depression and vulnerability/ stress interaction, with an incidence of $7 \%$ to $19 \% .{ }^{25}$ About $16 \%$ to $29 \%$ of mothers who kill their children also kill themselves. ${ }^{25}$}

\section{Acutely psychotic}

The mother kills the child responding to psychotic symptoms, with no rational motive. About $26 \%$ of infanticidal women have psychosis. ${ }^{26}$ The incidence of postpartum psychosis is 0.89 to 5 in 1000 women. ${ }^{27}$ Psychotic diagnoses include schizophrenia, bipolar affective disorder, schizoaffective disorder, psychotic depression, postpartum depression with psychotic features, and postpartum psychosis. Onset of symptoms usually becomes apparent within 2 weeks to 2 months postpartum. Clinical features of postpartum psychosis include elated, dysphoric, or labile mood, agitation, bizarre or disorganised behaviour and thought processes, and insomnia. Psychotic symptoms often include mood-incongruent delusions, hallucinations, or delusions of control, with content related to the infant or self (eg, harm to the infant or self). Neurohormonal changes during pregnancy and post-delivery period may affect mental health. Gonadol hormones (oestrogen, progesterone) may have mood modulator effects and their withdrawal after delivery may precipitate mood or psychotic disorder. However, transdermal oestrogen supplement has been shown to have no effect on reducing the risk of relapse in patients at risk of postpartum psychosis. ${ }^{28}$

\section{Unwanted child}

The mother kills the child because the child is regarded as a hindrance, particularly when the child is unplanned or has been unwanted since conception. Most such cases are neonaticides. ${ }^{29}$ Denial and concealment of pregnancy are typical features.

\section{Accidental/fatal maltreatment}

The mother unintentionally kills the child as a result of abuse or neglect. The mother attempts to discipline the child for annoying or disobedient behaviours. ${ }^{30}$ The parent typically said that they had assaulted the child in a fit of temper and had not meant to inflict serious harm. No intent to kill is identified. Cultural acceptance for corporal punishment is also a factor. Children may also die from neglect, secondary to acts of omission rather than commission, such as failure to provide adequate food, clothing, warmth, hygiene, medical assistance, or supervision..$^{31}$

\section{Spouse revenge}

The parent kills the child as a means of exacting revenge on the spouse. The anger towards the spouse is displaced to the child.

\section{Modern classifications of motives}

Modern classifications of motives overlap substantially with earlier categorisations. ${ }^{32} \mathrm{~A}$ vengeance motive for maternal filicide is relatively rare, whereas altruistic and acutely psychotic motives are more common. ${ }^{33,34}$ The two most common motives for maternal filicide are altruistic and maltreatment-related; the reduced prevalence of psychosisdriven filicide may be due to effective acute mental health services. ${ }^{35}$ However, the complexity of such offences means that they rarely fit into one category. Categorisation of 
offences can be subjective and vary between researchers. ${ }^{36}$

Thus, forensic psychiatry prefers a more functional classification to differentiate infanticides from neonaticides, and killings by psychotic women from killings by nonpsychotic women. ${ }^{37}$ Mothers who kill their newborns differ from mothers who kill their older children. ${ }^{37,38}$ The Table shows the differences in demographics and clinical characteristics between mothers committed neonaticide versus infanticide..$^{37,38}$

\section{Methods}

Data of mothers remanded to the Siu Lam Psychiatric Centre, which is a maximum security institution in Hong Kong for detainees who require psychiatric observation and treatment, from 2008 to 2016 for filicide were reviewed, as were data of filicide from the Child Fatality Review Reports published by the Social Welfare Department.

\section{Results}

From 2008 to 2016 eight mothers were remanded to Siu Lam Psychiatric Centre while awaiting trial for filicide. Subsequently, four were convicted of infanticide; the other four were convicted of manslaughter. Those convicted of infanticide (of three boys and one girl) were single and aged $<18$ years. They had concealed their pregnancies and received no antenatal care. They delivered at home and then either smothered or abandoned the newborn. They reported no suicidal attempts after the index offence and had no record of mental illness. They were given supervision orders instead of prison sentences.

In contrast, the four mothers convicted of manslaughter (of four girls and one boy aged 2 months to 13 years) were in their 30s and married. They were documented to have killed the victims by charcoal burning, strangulation, mutilation, or defenestration. They all attempted suicide immediately after the killing and had histories of mental illness: paranoid schizophrenia $(n=2)$, severe depressive disorder with psychotic symptoms $(\mathrm{n}=1)$, and recurrent depressive disorder $(n=1)$. They were sentenced to Hospital Orders for unspecified periods, under Section 45 of Mental Health Ordinance.

\section{Discussion}

In Hong Kong from 2006 to 2013, only 35 cases of filicide were documented, which ranged $71.4 \%$ among other offender-victim relationships in murder of children. ${ }^{39}$ Most victims were aged $<1$ year. In 2013, the homicide rate for children under 18 years was 0.6 per $100,000,{ }^{40}$ and for the general population was approximately 0.9 per $100,000 .^{41,42}$ The results of the present study are consistent with those of a previous study that found that mothers who commit neonaticide differ from mothers who commit filicide. ${ }^{37}$

In Hong Kong, the infanticide offence is described as: "Where a woman by any wilful act or omission causes the death of her child being a child under the age of 12 months but at the time of the act or omission the balance of her mind was disturbed by reason of her not having fully recovered from the effect of giving birth to the child or by reason of the effect of lactation consequent upon the birth of the child, then, notwithstanding that the circumstances were such that but for the provisions of this section the offence would have amounted to murder, she shall be guilty of infanticide, and shall be liable to be punished as if she were guilty of manslaughter." This provides a more lenient sentence for mothers who kill their infants. However, certain components of the infanticide provision have been challenged. It has been argued that 'disturbance of mind' is a lower threshold than that of 'abnormality of mind'. Thus, infanticide has been applied to women who have not been diagnosed with mental illness. Many infanticide convictions are based on mental states that could not be considered to reach statutory definitions of mental disorder, even on the most generous application of these criteria. ${ }^{24}$ Half of the women convicted of infanticide do not have any identifiable mental disorder. ${ }^{43,44}$ In addition, there has been criticism of the concept of "...

Table. Characteristics of women who committed neonaticide versus infanticide..$^{37,38}$

\begin{tabular}{|ll|}
\hline Neonaticide & Infanticide \\
$<25$ years old & $>25$ years old \\
\hline Unmarried & Married \\
\hline Unemployed & Employed \\
\hline Under-educated & Well-educated \\
\hline Lack of antenatal care; denial or concealment of pregnancy & Premeditate the murders \\
\hline No longer involved with baby's father & - \\
\hline Most were mentally ill & $20 \%$ to $30 \%$ were mentally ill \\
\hline Rare maternal suicide after the killing & $>50 \%$ of mothers attempted suicide after the killing \\
\hline
\end{tabular}


not having fully recovered from the effect of giving birth to the child or by reason of the effect of lactation consequent upon the birth of the child...”. Although the World Health Organization defines the postpartum period as 6 weeks, the law in Hong Kong outlines the period of infanticide within 12 months post-delivery. In addition, despite longstanding assumptions to the contrary, hormonal changes during pregnancy and delivery do not have a significant impact on a woman's mental health. ${ }^{45}$ Mental illness resulting from giving birth appears to be related to postpartum depression or psychosis, which often have defences under insanity provisions or diminished responsibility. There is a lack of causal relationship between lactation and tendency to kill children. ${ }^{46}$ Therefore, there appears to be no medical justification for the legislature on infanticide; recommending treatment rather than incarceration for those convicted of infanticide seems unfair. ${ }^{47}$

The courts in Hong Kong, New Zealand, England, and Wales apply infanticide generously. ${ }^{17}$ Although United States has no infanticide stature, $65 \%$ of maternal filicide cases that use the insanity defence are acquitted, compared with $0.1 \%$ in other cases. ${ }^{47}$ Not all infanticide cases make it to court hearing; only 27\% of all neonaticide cases in Finland between 1980 to 2000 were prosecuted and convicted. ${ }^{48}$ In British courts, $<50 \%$ of infanticide cases involving women are prosecuted, compared with $90 \%$ for men. ${ }^{49}$ In England and Wales, of those charged with infanticide, women are more likely to be granted bail than men (50\% vs. $0 \%)$; most men $(84.2 \%)$ are incarcerated, and most women $(87.2 \%)$ are given treatment.

One limitation of the present study is that data were obtained from a single psychiatric custodial centre and may not be representative. No data from the law enforcement agency or judiciary were available. Collaboration with other authorities is needed to provide more comprehensive data on epidemiological and legal outcomes.

\section{Conclusion}

In Hong Kong, the incidence of maternal filicide is low. However, the infanticide provision grants leniency to mothers, including those who show no evidence of mental illness.

\section{Declaration}

All authors have no conflicts of interest to disclose.

\section{References}

1. Bourget D, Grace J, Whitehurst L. A review of maternal and paternal filicide. J Am Acad Psychiatry Law 2007;35:74-82.

2. Stanton J, Simpson A. Filicide: a review. Int J Law Psychiatry 2002;25:1-14. Crossref

3. Osborne S, Lau I, Britton A. Home Office Statistical Bulletin: Homicides, Firearm Offences and Intimate Violence 2010/11: Supplementary Volume 2 to Crime in England and Wales 2010/11; 2012.
4. Marks MN, Kumar R. Infanticide in England and Wales. Med Sci Law 1993;33:329-39. Crossref

5. Bourget D, Bradford JM. Homicidal parents. Can J Psychiatry 1990;35:233-8. Crossref

6. Beyer K, Mack SM, Shelton JL. Investigative analysis of neonaticide. An exploratory study. Crim Justice Behav 2008;35:522-35. Crossref

7. Sahni M, Verma N, Narula D, Varghese RM, Sreenivas V, Puliyel JM. Missing girls in India: infanticide, feticide and made-to-order pregnancies? Insights from hospital-based sex-ratio-at-birth over the last century. PLoS One 2008;3:e2224. Crossref

8. Spinelli MG. Infanticide: Psychosocial and Legal Perspectives on Mothers Who Kill. Washington, DC: American Psychiatric Publishing; 2003.

9. Oberman M. Mothers who kill: coming to terms with modern American infanticide. Am Crim Law Rev 1996;34:1-110.

10. Lagaipa SJ. Suffer the little children: the ancient practice of infanticide as a modern moral dilemma. Issues Compr Pediatr Nurs 1990;13:24151. Crossref

11. Rhodes AM, Segre LS. Perinatal depression: a review of US legislation and law. Arch Womens Ment Health 2013;16:259-70. Crossref

12. Spinelli MG. Maternal infanticide associated with mental illness: prevention and the promise of saved lives. Am J Psychiatry 2004;161:1548-57. Crossref

13. Marks MN, Siddle K, Warwick C. Can we prevent postnatal depression? A randomized controlled trial to assess the effect of continuity of midwifery care on rates of postnatal depression in highrisk women. J Matern Fetal Neonatal Med 2003;13:119-27. Crossref

14. UNICEF. Hidden in Plain Sight: a Statistical Analysis of Violence Against Children. New York: United Nations International Children's Emergency Fund; 2014.

15. Marks MN, Kumar R. Infanticide in Scotland. Med Sci Law 1996;36:299-305. Crossref

16. Bennett MD Jr, Hall J, Frazier L Jr, Patel N, Barker L, Shaw K. Homicide of children aged 0-4 years, 2003-04: results from the National Violent Death Reporting System. Inj Prev 2006;12(Suppl 2):ii39-ii43. Crossref

17. Dean PJ. Child homicide and infanticide in New Zealand. Int J Law Psychiatry 2004;27:339-48. Crossref

18. Tanaka CT, Berger W, Valença AM, Coutinho ES, Jean-Louis G, Fontenelle LF, et al. The worldwide incidence of neonaticide: a systematic review. Arch Womens Ment Health 2017;20:249-56. Crossref

19. McKee G. Why Mothers Kill: a Forensic Psychologist's Casebook. Oxford: Oxford University; 2006. Crossref

20. Levene S, Bacon CJ. Sudden unexpected death and covert homicide in infancy. Arch Dis Child 2004;89:443-7. Crossref

21. Jason J, Carpenter MM, Tyler CW Jr. Underrecording of infant homicide in the United States. Am J Public Health 1983;73:1957. Crossref

22. Finkelhor D, Ormrod RK. Factors in the underreporting of crimes against juveniles. Child Maltreat 2001;6:219-29. Crossref

23. Resnick PJ. Murder of the newborn: a psychiatric review of neonaticide. Am J Psychiatry 1970;126:1414-20. Crossref

24. d'Orban PT. Women who kill their children. Br J Psychiatry 1979;134:560-71. Crossref

25. Friedman SH, Horwitz SM, Resnick PJ. Child murder by mothers: a critical analysis of the current state of knowledge and a research agenda. Am J Psychiatry 2005;162:1578-87. Crossref

26. Lambie I. Mothers who kill. The crime of infanticide. Int J Law Psychiatry 2001;24:71-80. Crossref

27. VanderKruik R, Barreix M, Chou D, Allen T, Say L, Cohen LS, et al. The global prevalence of postpartum psychosis: a systematic review. BMC Psychiatry 2017;17:272. Crossref

28. Kumar C, McIvor RJ, Davies T, Brown N, Papadopoulos A, Wieck A, et al. Estrogen administration does not reduce the rate of recurrence of affective psychosis after childbirth. J Clin Psychiatry 2003;64:1128. Crossref

29. Resnick PJ. Child murder by parents: a psychiatric review of filicide. Am J Psychiatry 1969;126:325-34. Crossref 
30. Baker JM. 'You can't let your children cry': Filicide in Victoria 19781988. MA thesis, University of Melbourne, Australia; 1991.

31. Wallace A. Homicide: the Social Reality. NSW Bureau of Crime Statistics and Research, Sydney, Australia; 1986.

32. Hatters Friedman S, Resnick PJ. Child murder by mothers: patterns and prevention. World Psychiatry 2007;6:137-41.

33. Haapasalo J, Petaja S. Mothers who killed or attempted to kill their child: life circumstances, childhood abuse, and types of killing. Violence Vict 1999;14:219-39. Crossref

34. McKee GR, Shea SJ. Maternal filicide: a cross-national comparison. J Clin Psychol 1998;54:679-87. Crossref

35. Kauppi A, Kumpulainen K, Karkola K, Vanamo T, Merikanto J. Maternal and paternal filicides: a retrospective review of filicides in Finland. J Am Acad Psychiatry Law 2010;38:229-38.

36. Flynn S, Swinson N, While D, Hunt IM, Roscoe A, Rodway C, et al. Homicide followed by suicide: a cross-sectional study. J Forens Psychiatry Psychol 2009;20:306-21. Crossref

37. Porter T, Gavin H. Infanticide and neonaticide: a review of 40 years of research literature on incidence and causes. Trauma Violence Abuse 2010;11:99-112. Crossref

38. Friedman SH, Holden CE, Hrouda DR, Resnick PJ. Maternal filicide and its intersection with suicide. Brief Treat Crisis Interv 2008;8:28391.
39. Child Fatality Review Panel (third report). Hong Kong; 2017.

40. Census and Statistics Department, Hong Kong. The Fertility Trend in Hong Kong, 2015.

41. Hong Kong Police Force. Crime Statistics Comparison.

42. Census and Statistics Department, Hong Kong. Mid-year Population for 2013.

43. Wilczynski A, Morris A. Parents who kill their children. Crim Law Rev 1993;31.

44. Rapaport E. Mad women and desperate girls: infanticide and child murder in law and myth. Fordham Urban Law J 2006;33:101-42.

45. Wisner KL, Stowe ZN. Psychobiology of postpartum mood disorders. Semin Reprod Endocrinol 1997;15:77-89. Crossref

46. Parker D. Forensic Psychiatric Reports. In: Brookbanks W, editor. Psychiatry and the Law: Clinical and Legal Issues. Wellington: Brooker's; 1996.

47. Stangle HL. Murderous Madonna: femininity, violence, and the myth of postpartum mental disorder in cases of maternal infanticide and filicide. William Mary Law Rev 2008;50:699-734.

48. Putkonen H, Collander J, Weizmann-Henelius G, Eronen M. Legal outcomes of all suspected neonaticides in Finland 1980-2000. Int J Law Psychiatry 2007;30:248-54. Crossref

49. Wilczynski A. Mad or bad? Child-killers, gender and the courts. Br J Criminol 1997;37:419-36. Crossref 